\title{
Education Responses to Climate Change and Quality: Two Parts of the Same Agenda?
}

Colin Bangay, UK Department for International Development

Nicole Blum, Institute of Education, University of London

\begin{abstract}
Increasing attention to climate change and the current global economic crisis have underscored the need for approaches to education that equip and empower people of all ages to deal with uncertain environmental, economic and political futures. A range of educational research and initiatives already exist which could support this aim, however, policy and discussion continue to focus on technical solutions or 'knowledge transfer' without seriously engaging with education. This paper suggests that education responses are needed which attend to provision of both appropriate educational infrastructure and relevant knowledge and skills. It also explores the connections between education for sustainable development (ESD) and education quality, and argues that these frameworks already support potentially effective education responses to climate change.
\end{abstract}

Keywords: climate change, education for sustainable development, quality

\section{Introduction}

In a recent speech, John Beddington, the UK government's chief scientist, warned of the potential for a 'perfect storm' in which mutually reinforcing drivers of population growth and the increased consumption of food, water and energy exacerbated by the impact of climate change led to famine, civil unrest and mass migration (BBC 2009a). The potential impact of the population growth, consumption, climate change nexus on the Millennium Development Goals (MDGs) was brought into stark focus in the 2008 UN Human Development Report:

'Climate change is hampering efforts to deliver the MDG promise. Looking to the future, the danger is that it will stall and then reverse progress built-up over generations not just in cutting extreme poverty, but in health, nutrition, education and other areas.' (UNDP 2007: 1)

In the UK, the government's White Paper on development has presented climate change as a current challenge - not a future threat - and establishes climate change as one of the three priorities that will frame the UK development effort (DFID 2009). The influential Stern Report also identified three key elements in response to climate change, of which two technological transfer and behavioural change - have clear implications for education (see Stern 2007: xviii) ${ }^{1}$.

This paper details the possible impacts of climate change and associated environmental degradation on education provision and demand, and also sets out associated responses. It argues that although the role of education in addressing the challenges of climate change is being increasingly recognised ${ }^{2}$, the capacity of education to contribute to adaptation and mitigation measures has yet to penetrate mainstream development thinking. In order for this to happen it is argued firstly that the potential of the full range of educational channels formal and non-formal, and from primary through tertiary and adult education - must be highlighted. Secondly, educationists must recognise the dangers of labelling and the preconceptions/ misconceptions that often arise when using terms such as 'environmental

\footnotetext{
${ }^{1}$ See also Carter et al (2006) for a thorough critique of Stern.

${ }^{2}$ For example, see recent statements from the G8: http://www.g8italia2009.it/G8/Home/G8G8 Layout locale-1199882116809 Atti.htm.
} 
education' or 'education for sustainable development' - especially as such misconceptions have tended to undermine the areas' contribution to debate and discussion.

While recognising the importance of content-specific concepts such as ecology, we do not see education's response to climate change as simply the provision of new curriculum inputs; rather, the challenges of climate change require all concerned to look to fundamentals and examine the degree to which existing educational provision is adapted to and prepares people for radically different futures. Furthermore, although the focus of this paper is largely on potential education impacts and responses to climate change in developing country contexts, we also recognise the central importance of the exploration of these issues in industrialised countries. In essence, in the face of the daunting challenges of climate change, we argue that an educational response to climate change must be integral rather than additional to broader quality/ relevance debates and to any reform they generate.

\section{Climate Change and Environment - Impact and Response}

Climate change is a key priority for international development as its impact is likely to be disproportionately felt in developing countries. This is because developing countries are generally warmer, more prone to rainfall variability, more dependent on agriculture - the most climate-sensitive of economic sectors - and as a result of low income have limited risk mitigation infrastructure, both physical and financial (e.g. insurance) (Stern 2007: 93-97). Increased instances of drought, flooding and severe weather events as well as incremental environmental change through processes such as inundation, desertification and salination are likely to exacerbate existing problems related to agricultural production, communicable diseases, migration streams, poverty and conflict (cf. Smith and Vivekananda 2007; WHO 2008; UNICEF UK 2008). Consequences for the majority of people in Asia and Africa as well as those living in small island developing states are likely to be particularly significant, although the specific nature of climate threats will vary between countries (see Tables 1 \& 2).

Table 1: Projected Impact of Climate Change in Asia, Africa \& Small Island Developing States

\begin{tabular}{|c|c|c|c|c|c|c|}
\hline & $\begin{array}{c}\text { Water } \\
\text { shortage }\end{array}$ & $\begin{array}{c}\text { Food } \\
\text { production }\end{array}$ & Disease & Flooding & Fire & $\begin{array}{l}\text { Corals and } \\
\text { Ice }\end{array}$ \\
\hline Africa & $\begin{array}{l}75-250 \text { million } \\
\text { people at risk } \\
\text { by } 2020\end{array}$ & $\begin{array}{l}\text { Reduced } \\
\text { yields across } \\
\text { the continent, } \\
\text { in some } \\
\text { countries by } \\
\text { as much as } \\
50 \% \text { by } 2020\end{array}$ & $\begin{array}{l}\text { Malaria likely } \\
\text { to reduce its } \\
\text { range in } \\
\text { Southern } \\
\text { Africa but } \\
\text { extend its } \\
\text { range to } \\
\text { Eastern } \\
\text { highlands }\end{array}$ & $\begin{array}{l}\text { High risk to } \\
\text { large coastal } \\
\text { cities: e.g. } \\
\text { Lagos and } \\
\text { Alexandria }\end{array}$ & $\begin{array}{l}\text { Increased } \\
\text { threat of } \\
\text { burning to } \\
\text { many forests }\end{array}$ & $\begin{array}{l}\text { Red Sea and } \\
\text { East African } \\
\text { corals at risk } \\
\text { from bleaching }\end{array}$ \\
\hline Asia & $\begin{array}{l}120 \text { million - } \\
1.2 \text { billion } \\
\text { people at risk } \\
\text { by } 2020\end{array}$ & $\begin{array}{l}\text { - } 2.5-10 \% \\
\text { decrease in } \\
\text { crop yields in } \\
2020 \text { 's } \\
\text { - Up to } 49 \\
\text { million at risk } \\
\text { of hunger }\end{array}$ & $\begin{array}{l}\text { Flooding and } \\
\text { high } \\
\text { temperatures } \\
\text { increase risk } \\
\text { of infectious } \\
\text { diseases, } \\
\text { especially } \\
\text { cholera and } \\
\text { typhoid }\end{array}$ & $\begin{array}{l}\text { - } 2.5 \text { million } \\
\text { people flooded } \\
\text { by } 2050, \\
\text { mostly in the } \\
\text { Ganges - } \\
\text { Brahmaputra } \\
\text { and Mekong } \\
\text { mega-deltas } \\
\text { - Increased } \\
\text { incidence of } \\
\text { intense } \\
\text { typhoons, } \\
\text { rising sea } \\
\text { levels and } \\
\text { storm surges }\end{array}$ & $\begin{array}{l}\text { - Increased } \\
\text { mortality from } \\
\text { severe heat } \\
\text { waves for the } \\
\text { southern and } \\
\text { eastern parts } \\
\text { of the } \\
\text { continent, and } \\
\text { possibly also } \\
\text { Siberia } \\
\text { - Reduced } \\
\text { mortality from } \\
\text { serious cold } \\
\text { events }\end{array}$ & $\begin{array}{l}\text { - Very } \\
\text { substantial or } \\
\text { complete loss } \\
\text { of Himalayan } \\
\text { glaciers by } \\
2035 \\
\text { - Loss of } 30 \% \\
\text { of coral reefs }\end{array}$ \\
\hline
\end{tabular}




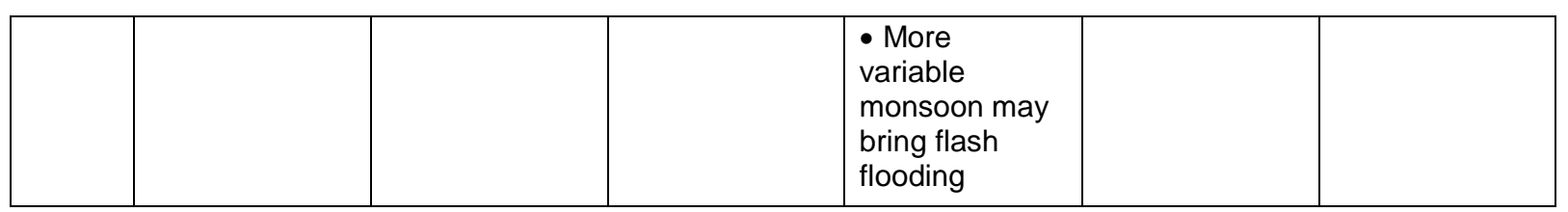

Source: Walker and King (2008: 60) (Data reported in Fourth Assessment of the International Panel on Climate Change)

Table 2: Six Climate Threats and Countries Most at Risk

\begin{tabular}{|l|l|l|l|l|}
\hline Drought & Flood & Storm & Coastal 1m & Agriculture \\
\hline Malawi & Bangladesh & Philippines & All low lying island states & Sudan \\
\hline Ethiopia & China & Bangladesh & Vietnam & Senegal \\
\hline Zimbabwe & India & Madagascar & Egypt & Zimbabwe \\
\hline India & Cambodia & Vietnam & Tunisia & Mali \\
\hline Mozambique & Mozambique & Moldova & Indonesia & Zambia \\
\hline Niger & Laos & Mongolia & Mauritania & Morocco \\
\hline Mauritania & Pakistan & Haiti & China & Niger \\
\hline Eritrea & Sri Lanka & Samoa & Mexico & India \\
\hline Sudan & Thailand & Tonga & Myanmar & Malawi \\
\hline Chad & Vietnam & China & Bangladesh & Algeria \\
\hline Kenya & Benin & Honduras & Senegal & Ethiopia \\
\hline Iran & Rwanda & Fiji & Libya & Pakistan \\
\hline
\end{tabular}

= Middle income country (all others low income)

Source: World Bank (2009: 19)

Discussions regarding human-induced climate change and the nature and funding of action to address impact are politically charged with issues of distributive justice (Klinsky and Dowlatabadi 2009). There is an obvious inverse relationship between historical responsibility for climate change, which predominantly lies with industrialised countries $\left(\mathrm{CO}_{2}\right.$ levels began their dramatic rise following the industrial revolution), and those vulnerable to its impacts. There are clear tensions in addressing a global problem which is characterised by (i) impacts of such varying geographic intensity, (ii) the varying degrees of 'accountability' nations will accept for cumulative 'historic' $\mathrm{CO}_{2}$ emissions, and (iii) the 'right' of developing countries to follow the 'high carbon' development path that fuelled the economic growth of industrialized nations. This throws up a further paradox: 'development' has traditionally resulted in increasing levels of consumption, further adding to competition for resources. This has most recently been demonstrated in the changing diet of the growing middle classes of newly industrialized countries, who are exercising the choice afforded them by their new economic power to engage in greater consumption of more resource-intensive, grain-fed meat production. When considered in conjunction with the increased competition in use of agricultural land for food vs. bio-fuel production (which is likely to further intensify as oil reserves dwindle), the potential implications for food availability and hunger are apparent.

What is evident from all of this is that climate change presents an international challenge of a magnitude that we have not previously encountered. Its impacts have the potential to exacerbate existing tensions and create new ones which, in turn, have implications for stability and security from local to international levels. An effective response to climate change and its associated bio-physical and socio-economic impacts will therefore need to be multifaceted and inherently political. Furthermore, in all of the high level discussions of emissions caps and 'carbon trading' schemes it is important that the role of education is not overlooked. Education has already been proven to have an impact on key issues in population dynamics: fertility, child mortality, etc (cf. Bledsoe et al 1999). As has been noted: 
'Education is as important as health: a well-educated population is better equipped to recognise in advance the threats posed by a changing climate and to make preparations. This is one of many areas where ordinary development aid, properly directed, can potentially achieve multiple objectives at once, serving classic development and human rights aims while at the same time contributing to societies' long-term ability to adapt to climate change.' (International Council on Human Rights Policy 2008: 26-27)

\section{Climate/ Environmental Change and Education - Supply, Demand \& Learning Implications}

To date the majority of research on education and climate change has focused on the impact of climate and associated environmental change on schooling. According to two recent publications: Save the Children's (2008) 'Legacy of Disasters' and UNICEF UK's (2008) 'Our Climate, Our Children, Our Responsibility', it is children who will be hardest hit by the effects of climate change. These impacts will be seen, for instance, in the direct effects on educational provision associated with increasing incidence of severe weather events (e.g. drought, flooding, cyclones, heat waves). Over the longer term, incremental environmental changes (e.g. sea level change, salination, changes in season patterns, desertification, soil erosion, species loss, etc.) are also likely to result in deteriorating livelihoods which impact upon both household expenditure on schooling and the nutritional status of children.

Evidence of the supply side consequences of extreme weather events is already emerging. The aftermath of Cyclone Sidr, which struck Bangladesh in November 2007, left 74 government primary schools destroyed and another 8,817 damaged. An estimated 103,664 children were affected as a result. The estimated cost of reconstruction and refurbishment was more than US\$ 82 million (see Das 2008). Similarly, the 2000 flood in Cambodia destroyed approximately $18 \%$ of the country's schools, impacting upon the education of 500,000 children and costing $\$ 1.6$ million in rehabilitation costs. Subsequent research in Cambodia has also demonstrated that school absenteeism and drop out are higher in floodprone areas. Moreover, there is evidence that flooding inhibits completion of the school programme, with schools located in flood-prone areas subject to at least one and a half months of closure due to flooding (Asian Disaster Preparedness Center 2008).

The cumulative effects of extreme weather events on both initial enrolment and longer term educational performance are not well known. Research in India, however, concludes that women born during flood years in the 1970s were $19 \%$ less likely to have attended primary school (UNDP 2007). It would also seem safe to conclude that interrupted/ reduced access to education has a detrimental impact on learning outcomes, reducing the likelihood that children and young people - and especially girls - will be able to break the cycle of poverty (Elimu Yetu Coalition 2005). A further important implication that the Cambodia and Bangladesh examples demonstrate is the significant financial burden that rehabilitation costs exert on constrained education budgets. Emergency responses to extreme weather events and their aftermath thus have the potential to undermine investment in the longer term quality improvement of education provision.

Over the longer term, climate change impacts in combination with factors such as population pressure are likely to lead to environmental degradation and the related deterioration in livelihoods. Associated reductions in household income will influence decisions regarding the number and gender of children sent to school as well as whether there is continued support for their attendance. Moreover, deteriorating livelihoods are likely to increase the time required to secure clean water and fuel, and to care for siblings and the sick. Research suggests that in all instances such effects are likely to disproportionately affect girls and impact on gender equity and female student performance. 
A further concern associated with deteriorating livelihoods is the impact this will have on nutrition and parasitic burden. Estimates already suggest that 200 million children under the age of five fail to reach their potential cognitive development because of poor health and nutrition. These children predominantly live in South Asia and sub-Saharan Africa - the regions to be hit most hard by climate change. For example, research on under fives in Ethiopia and Kenya suggests they are 36\% (Ethiopia) and 50\% (Kenya) more likely to be malnourished if they were born during a drought (UNDP 2007). Recent research further notes:

\begin{abstract}
'...there is strong evidence to suggest that school-aged children who suffer from protein-energy malnutrition, hunger, or who lack certain micronutrients in their diet (particularly iron, iodine or vitamin A) or who carry a burden of diseases such as malaria, diarrhoea or worms do not have the same potential for learning as healthy and well-nourished children, and that they are more likely to repeat grades, drop out early and fail to learn adequately due to poor attention, low motivation and poor cognitive function.' (CREATE 2008)
\end{abstract}

This loss of human potential is estimated to lead to a $20 \%$ decrease in adult income and also has broader implications for national development (Granther-McGregor et al 2007, op cit CREATE 2008).

In addition to impeding cognitive development, poor nutrition undoubtedly lowers resistance to disease. Recent multi-disciplinary research published within The Lancet describes climate change as '.. the biggest global health threat of the 21st century' (Costello et al 2009: 1693). As Table 1 notes, climate change is set to alter the range of vector-borne diseases such as malaria, dengue fever and water-borne infections. Studies cited by Jukes, Drake and Bundy (2008) indicate malaria has a significant impact upon school attendance. Malaria reportedly accounts for a loss of $11 \%$ of school days for primary and $4.3 \%$ of secondary students in Kenya, while in Senegal malaria accounted for $36 \%$ of all absence during the high transmission season (Jukes, Drake and Bundy 2008: 41-42). Clearly malaria is not confined to students alone, with the disease also impacting on teacher attendance. Moreover, as Jukes et al (2008) suggest the impact of malaria on learning is likely to be amplified by the cumulative effect of absences which result from repeated bouts of the disease over several years. The potential impacts of malaria on learning alone are brought into sharp focus by the IPCC's estimate that the global additional population at risk of malarial infection as a result of climate change is between 220 and 400 million.

\title{
4. Education - A Critical Element in the Response to the Challenges of Climate Change
}

While there is emerging awareness of the current and potential impacts of climate/ environmental change on education provision and learning, it is also clear that education formal and non-formal, from primary through to tertiary and adult education - has an important role to play in addressing this change.

Since the 1960s, a large body of research has sought to understand the links between increasing knowledge of environmental and development concerns and both social and environmental change ${ }^{3}$. This includes work carried out using various terms and definitions, including 'development education', 'environmental education', 'education for sustainable development' and many others (cf. Bourn 2008a, Scott and Vare 2008, Palmer 1998,

\footnotetext{
${ }^{3}$ Notably, much of this work has been carried out in industrialised countries and drawing on largely Western approaches to education; more research which draws on and explores Southern perspectives is needed in the future.
} 
Sterling 2001) ${ }^{4}$. For the purposes of this paper, the term 'education for sustainable development' (ESD) is used to refer to this large area of research, policy and action.

The concept of ESD itself emerged in the late 1980s alongside international discussions of environmental protection and sustainable development. It was given much of its shape at the United Nations Conference on Environment and Development in Rio de Janeiro in 1992, and in the resulting Agenda 21:

'Education, including formal education, public awareness and training should be recognized as a process by which human beings and societies can reach their fullest potential. Education is critical for promoting sustainable development and improving the capacity of the people to address environment and development issues. While basic education provides the underpinning for any environmental and development education, the latter needs to be incorporated as an essential part of learning.' (UNCED 1992: section 36.3)

ESD continues to receive international attention through the current UNESCO-led UN Decade of Education for Sustainable Development (2005-2014). The aims of the Decade are to integrate the principles, values and practices of sustainable development into all aspects of education and learning, and to encourage changes in behaviours that allow for a more sustainable and just society for all (UNESCO 2006). According to UNESCO (2006), the key features of ESD include:

- a concern for education of high quality (which is interdisciplinary and holistic, fosters critical thinking and problem solving, and is participatory and locally relevant),

- an attention to values (including respect for others, for difference and diversity, and for the environment),

- an acknowledgement that ESD will be shaped by diverse perspectives and will take place across a range of learning spaces (formal and informal, and from early childhood through adult life).

The key point here is that both of these international policy frameworks suggest that ESD does not simply represent a single, new curriculum area for schools (e.g. environmental studies), but rather is a more integrated approach to providing appropriate education and training in a diverse and rapidly changing world. Furthermore, both frameworks strongly connect efforts in ESD to international interest in both increasing access to education and providing education of high quality. These assertions are supported by a significant body of academic research and policy in the area.

\section{Education, Environmental Learning and Development Agendas}

Concerns about access and quality education are central to both the Millennium Development Goals (MDGs) and Education for All (EFA), as well as within most international and national development strategies. It is widely agreed that a lack of education is a part of the definition of poverty, and also that the provision of education is a means to reduce it. The achievement of universal primary schooling, greater levels of participation in post-primary education and training, and improved access for girls and other vulnerable children are critical to long term improvements in productivity, preventive health care, the empowerment of women, and reductions in inequality.

\footnotetext{
${ }^{4}$ More recently, the term 'climate change education' has also emerged in response to international attention to its impacts. This potentially new area of work is not yet supported by research, and so it is uncertain how useful the term may be in the future.
} 
Recent research on access to primary education, however, highlights that simple provision of basic facilities and increased enrolment does not in itself ensure positive educational impacts. Rather, access must be meaningful - in other words, characterised by high attendance rates, progression through grades with little or no repetition, and learning outcomes which confirm that basic skills are being mastered (Lewin 2007). Furthermore, education provision is likely to be more meaningful, and participation in learning processes more active, when programmes deliver knowledge and skills which are relevant to local contexts and needs.

This understanding is in sharp contrast to the tendency for international education and development agendas to focus rather narrowly on certain issues - for instance specific types of knowledge and skills (e.g. literacy, numeracy, vocational skills) or educational arenas (e.g. basic/ primary education). While sustained and detailed engagement with these issues is clearly important, too limited a focus tends to lead to 'silo' education efforts which chip away at single, albeit key issues (e.g. contemporary work on gender equality and fragile states) without more fully integrating them into broader approaches to education and development. It also often results in quite limited approaches to addressing the complex links between provision, access, learning and development (see, for example, King, McGrath and Rose 2007).

Research on environmental teaching and learning is one of these important issues which has remained on the margins of research and policy on education and international development. In many cases, it is seen as an 'alternative education' which has little value to mainstream educational development goals, and is therefore widely addressed through the 'add-on' of environmental topics in curricula and training programmes. A recent European Commission publication, for instance, advocates the addition of awareness-raising in schools, new topics for vocational training, and the creation of professional experts through post-graduate training programmes as appropriate sector strategies for addressing climate change (European Commission 2009). Similarly, while there is significant discussion by international aid donors of the need for 'capacity building' and 'knowledge transfer' in both developed and developing countries in order to address climate change, the connections to education, learning and development as a whole are very poorly articulated (cf. World Bank 2008, USAID 2007).

While such early efforts are undoubtedly an important part of addressing climate change, their promotion appears to be rooted in somewhat oversimplified understandings of the relationships between education, learning and change. Simply put, it is often assumed that new inputs (e.g. curricula, textbooks, training programmes) will result in significant individual and systemic change. While addressing climate change undoubtedly requires new knowledge and skills (see section 6.2), several decades of educational research have also illustrated the complexity of learning processes, and have roundly critiqued 'transmission' theories which suggest that learning is the simple transfer of information from teacher to student (see Illeris 2007: 30-50). Rather, learning is better understood as a complex process of acquisition, accommodation, interpretation and capacity change, and which is influenced by a number of individual and social factors. The work of key theorists such as Vygotsky and Piaget, for instance, continues to influence educational research on the complex nature of learning and its connections to curriculum development and assessment systems. This influential body of writing on learning is also the foundation for further expanded understandings of the links between learning and individual or social change - often labelled as 'transformative':

'Transformative learning refers to the process by which we transform our taken-forgranted frames of reference (meaning perspectives, habits of mind, mind-sets), to make them more inclusive, discriminating, open, emotionally capable of change, and 
reflective, so that they may generate beliefs and opinions that will prove more true and justified to guide action.' (Mezirow 2000: 7-8)

Ideas about the potentially transformative nature of learning are also central to work which explores teaching and learning about environmental and development issues, for example in the well-respected writings of Freire $(1972,1976)$ and Huckle and Sterling (1996). This significant body of work has examined the potential for methods and approaches to education and learning which expand the learner's understanding of him/ herself and of the world around him/ her, and potentially lead to individual or social change. While more work is needed to understand these complex processes more fully (cf. Rickinson 2001, Heimlich and Ardoin 2008), a number of researchers have already argued that learning which inculcates skills such as critical thinking and problem solving is key to addressing climate change and sustainable development, and to living in a rapidly changing world more generally (cf. Gough and Scott 2007, Bourn 2008b).

At the root of much of this discussion is a fundamental question about the aims of education in development generally, and of educational responses to climate/ environmental change in particular:

'Some argue that the ultimate purpose of education is to affect individuals' behaviors and that conservation education, among other areas, specifically calls for behavioral change. Others contend that the primary role of education is to facilitate an individual's intellectual capability and not to impose on individuals how they should live. To that end, environmental education represents a process for intellectual growth using environment as the context.' (Heimlich and Ardoin 2008: 215)

In other words, in the context of climate change, is the aim of educational programmes to teach people (of all ages) to perform certain 'appropriate' or 'correct' behaviours (e.g. conserving energy, recycling, reducing carbon consumption) or is it to support them to develop the capacities to address rapid change and uncertainty?

There are, of course, researchers with views that could be placed along the whole spectrum between these two disparate orientations (see Courtenay-Hall and Rogers 2002, Kollmuss and Agyeman 2002). However, a significant body of research in the field - as well as within educational research more generally - strongly critiques the notion of behaviour change as the key aim of education:

'Once we locate "behaviour change" at the top of the educational agenda, it is all too easy for schooling to slip from education to indoctrination. It is also all too easy for students to catch on quickly, and to develop the attitude of giving their teachers what they seem to want to hear. In the process, what students can end up learning most about is living inauthentically, or engaging in cynical behaviour, or yet another reason to consider dropping out of school. Promoting "pro-environmental behaviour" is thus not a salutory focus for the design of environmental education programs, the assessment of environmental learning, the prediction of future capacity of students to engage in "responsible environmental behaviour", and the evaluation of environmental education programs.' (Courtenay-Hall and Rogers 2002: 285) ${ }^{5}$

This discussion includes not only educational efforts in schools, but also in other educational arenas, including higher education:

\footnotetext{
${ }^{5}$ See also Robottom and Hart (1993), Courtenay-Hall (1997) and Jickling and Spork (1998).
} 
'At its heart, the distinction between these two positions comes down to one of confidence. If we are secure in our estimation of the worth of what we already know, and clear about what we want to happen next, then we can certainly decide what the next generation needs to know, and universities can teach it to them. On the other hand, if we recognise and acknowledge our human failures, and are nervous about the future, then we need universities to prepare a generation that will understand, and act, better than any of us presently do.' (Gough and Scott 2007: xi)

If the role of education is to help learners of all ages to develop the knowledge, skills and capacities which enable them to think critically, to solve problems, and to address uncertainty, then the focus of climate change interventions should not simply be on new inputs/ content (although these are also necessary), but also on more holistic ways of addressing climate change through high quality teaching and learning.

This agenda also runs parallel to even longer-standing research and policy discourses about the central role of education in promoting individual and social development. As noted above, it also draws on at least two core strands of educational research and policy in development - access and quality - and integrates these with thinking on environmental learning and its impacts.

An emerging body of research, for example, has begun to identify strong links between EFA and ESD agendas. As a recent policy paper for UNESCO highlighted, the areas share a number of key concerns:

\begin{tabular}{|c|c|c|}
\hline EFA & EFA/ ESD Overlap & ESD \\
\hline $\begin{array}{l}\text { Basic education and literacy } \\
\text { available to all learners } \\
\text { Particularly addresses those } \\
\text { who are excluded from } \\
\text { quality basic education }\end{array}$ & $\begin{array}{l}\text { Commitment to quality education } \\
\text { Seeing education as a human right } \\
\text { Promotion of human rights, especially gender } \\
\text { equality and rights for marginalised people } \\
\text { Concern to improve the quality of life, reduce } \\
\text { poverty, improve health } \\
\text { Importance of primary education } \\
\text { Participation of all in education and development: } \\
\text { governments, civil society organizations (CSOs), the } \\
\text { private sector, communities and individuals } \\
\text { Includes non-formal learning }\end{array}$ & $\begin{array}{l}\text { Broader purposes beyond } \\
\text { education } \\
\text { Relevance and } \\
\text { importance of ESD for all } \\
\text { within or outside planned } \\
\text { learning activities } \\
\text { Includes those in } \\
\text { privileged positions in } \\
\text { societies where } \\
\text { consumerism dominates } \\
\text { Emphasis on basic } \\
\text { values, processes and } \\
\text { behaviours as part of all } \\
\text { learning }\end{array}$ \\
\hline
\end{tabular}

Source: Wade and Parker (2008: 4)

In addition, ESD shares an interest in the universal provision of basic education and literacy both for their own value as well as because they are pre-requisites for quality environmental learning; this is particularly important in preparing learners to address complex global concerns like climate change. Both EFA and ESD can also play a significant role in poverty reduction by contributing to the development/ protection of human, social and natural capital:

'... poverty can be seen as resulting from a lack of a sufficient amount of any of these elements. ESD has a strategic role in helping to develop these complex understandings and in particular the links between degradation and depletion of the natural environment and poverty. With its broad remit it also enables issues of poverty to be looked at in conjunction with issues of appropriate development both in 
Citation: Bangay, C. and Blum, N. (2010) Education Responses to Climate Change and Quality: Two Parts of the Same Agenda? International Journal of Educational Development 30(4): 335-450.

individual terms, and in relation to communities and groups.' (Wade and Parker 2008: 14)

The shared concern of both EFA and ESD with both quality education and quality of life also links them with research and writing on quality more generally. The 2005 EFA Global Monitoring Report, for instance, identified five inter-related dimensions for quality education: learner characteristics, context, enabling inputs, teaching and learning, and outcomes (UNESCO 2004: 35). Attempts have also been made to outline the range of competencies and capabilities which people need in the contemporary world, including: 
Citation: Bangay, C. and Blum, N. (2010) Education Responses to Climate Change and Quality: Two Parts of the Same Agenda? International Journal of Educational Development 30(4): 335-450.

\begin{tabular}{|l|l|}
\hline \multicolumn{2}{|l|}{ Learning Capabilities for the $2 \mathbf{1}^{\text {st }}$ Century } \\
\hline Knowledge & $\begin{array}{l}\text { The basic learning content including core subjects; international language ability, and broad- } \\
\text { based scientific literacy; as well as self knowledge. }\end{array}$ \\
\hline $\begin{array}{l}\text { Competencies } \\
\text { and skills }\end{array}$ & $\begin{array}{l}\text { These include foundational skills (literacy, oral expression, numeracy); critical thinking and } \\
\text { problem solving skills (reasoning, recognising and questioning patterns; dealing with } \\
\text { uncertainties; analysing, synthesising and evaluating information); planning and management } \\
\text { skills; life-long learning skills (learn how to learn, to adapt knowledge to new contexts, and to } \\
\text { engage in self-directed learning); cross-cultural communication skills (ability to communicate } \\
\text { in different cultural contexts, negotiate and resolve conflicts); and information, media and } \\
\text { technology skills. }\end{array}$ \\
\hline $\begin{array}{l}\text { Attitudes and } \\
\text { behaviours }\end{array}$ & $\begin{array}{l}\text { Flexibility and adaptability; risk taking; the willingness to take initiative; motivation; respect for } \\
\text { self and others; sense of commitment; empathy; responsibility for ones actions and work. }\end{array}$ \\
\hline Values & $\begin{array}{l}\text { Solidarity; gender equality; tolerance; respect for difference; mutual understanding; respect for } \\
\text { human rights; non-violence; respect for human life; and dignity. }\end{array}$ \\
\hline
\end{tabular}

Source: Haichour, Metzger and Pigozzi (2007)

This emphasis on the development of capabilities as an indication of quality is strongly connected to core thinking in development (e.g. Sen 1999, Nussbaum 2000, Chambers 2008). It also highlights the need for greater attention to the fundamental aims and goals of education in development (i.e. provision of content vs. enabling learning processes), as well as revealing a shared agenda for improved learning:

'Quality education and education for sustainable development seek to achieve similar learning outcomes - those that enable learners to make decisions and choices that foster sustainable development - and are thus complementary.' (Pigozzi 2007: 27).

Rather than representing an entirely new area of theory, policy or practice, therefore, thinking in ESD (and related areas of environmental education, etc.) is better understood as sharing many of the key concerns of education and development, and particularly the need for education which develops human potential to address future change and challenges. Unfortunately, this area of thinking has so far been largely ignored by mainstream development thinking, and so such potential contributions have gone relatively unacknowledged.

\section{Educational Responses to Climate Change}

In practical terms, the integration of quality environmental learning into existing education systems represents both immediate and longer term challenges for responding to climate change. The immediate challenge is to climate proof education systems (adaptation), while the longer and even more challenging task is to develop education systems that equip learners with the requisite skills, knowledge and attributes to deal with future challenges. In many ways the latter is nothing new, but is at the heart of the very purpose of both education and development agendas. What has changed, however, is the nature and urgency of the challenges faced - locally, nationally and globally. Figure 1 provides a generalised chronological view of the possible sequencing of educational responses. 
Figure 1: Educational Responses to Climate Change and Generalised Sequential View

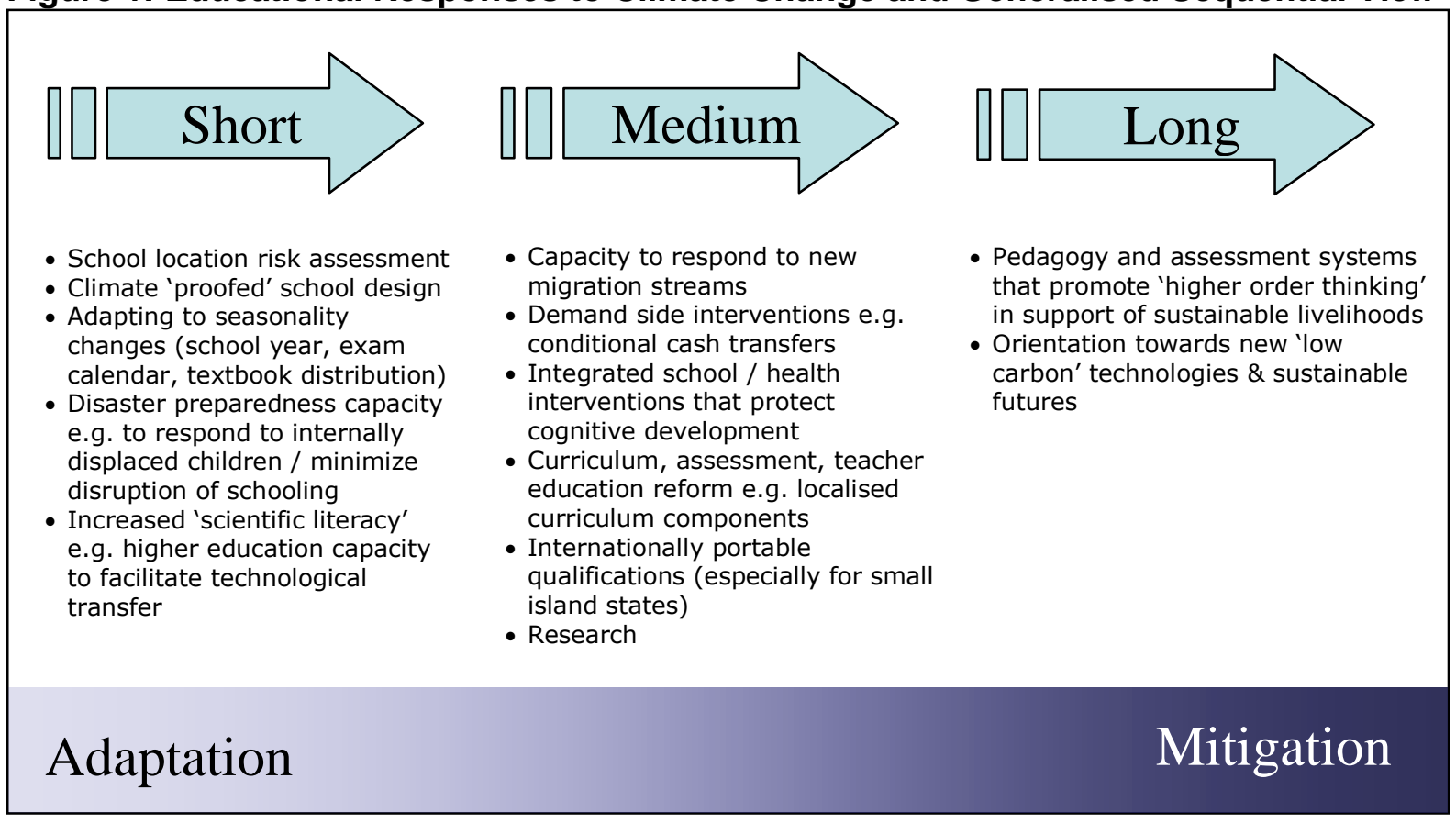

Article 6 of the United Nations Framework Convention on Climate Change (UNFCCC) (also known as the New Delhi work program) directs countries to consider education, training and public awareness as integral to responses to climate change. Increasingly, country plans developed utilising the UNFCCC framework do incorporate education-specific elements. However, the degree of success of such plans will be determined by the extent to which countries recognise and are able to adequately resource responses to the challenges posed by climate change, namely: extreme weather events, changes in seasonality, population movements, and demand side and health impacts on enrolment, attendance and educational performance. These challenges will need to be addressed both in terms of educational infrastructure as well as teaching and learning.

\subsection{Climate Proofing Education Infrastructure}

'Climate change proofing' of educational infrastructure in order to minimise the risks and associated costs of weather-related damage is clearly an important starting point. This would entail better risk assessment in making decisions about school location and improved building design/ maintenance to better withstand severe weather events (see Das 2008) as well as slower incremental change (e.g. school / community water catchment systems). A concerted focus on school design and upgrading offers opportunities both to reduce environmental impact in terms of the materials used (e.g. minimising use of burnt bricks and tiles in construction, discontinuing the use of wood-burning stoves), and also to incorporate design elements which create improved learning environments (e.g. levels of natural lighting, sanitation facilities, reduced noise from rain impact, spaces conducive for learning).

The impacts of climate change are widely predicted to result in significant population movements. Save the Children's (2008) 'Legacy of Disasters' report, for instance, cites an estimate that by 2010 there will be 50 million 'environmentally displaced people'. The scale of such events ranges from 'short term' population displacement resulting from extreme weather events to wholesale international population movements associated with the inundation of low lying islands. The need to respond to periodic forced in- and out-migration of student populations who are displaced by extreme weather events suggests the need for 'portable schools' and/ or schools in 'buffer zones' capable of accommodating expanded numbers of students at short notice. In addition to the physical demands of more school 
places and teachers, such movements present additional challenges in dealing with both the specific educational needs of immigrants (e.g. language of instruction) as well as the potential for conflict at the level of the classroom and community. As has recently been seen in the UK, for instance, responding to rapid localised increases in education demand resulting from immigration can be challenging (see BBC 2009b).

In extreme circumstances, such as those potentially facing some low lying islands in the Pacific, there is a need to make preparations for mass evacuation to mainland nations and also to consider the international 'portability' of qualifications. In the most severe incidences it is likely that whole national populations will have to evacuate areas that are inundated or become uninhabitable. Investment and preparations are therefore needed to ensure that these populations have the skills and qualifications which will assist them in the relocation process, and in re-establishing healthy lives and stable livelihoods in new locations.

In addition to extreme weather events, climate change is also already being implicated in changes in seasonality. In most countries seasons have shaped the timing of the school year, and in many developing countries key processes in the management of educational provision have evolved to accommodate seasonal patterns. These include the timing and duration in which school building and maintenance is practicable, the examination cycle and textbook distribution. Similarly, disease incidence (and by implication school attendance) is also known to follow seasonal cycles. Given the significance of seasonality in many developing countries, school systems will therefore need the capacity to align with seasonal change. Countries with significant regional climactic differences will also need to consider the benefits of decentralised decision making about the timing of key education dates and processes.

The impact of $\mathrm{CO}_{2}$ already released into the atmosphere will make further climate change inevitable. In turn, this is set to contribute to environmental degradation and associated deterioration in livelihoods and with this the ability of households to enrol and retain children in school. The potential cost of demand side interventions such as conditional cash transfers (CCTs) to counter such economic impacts are likely to be large and sustained. Developing better understandings of the potential and pitfalls of such demand side/ cash transfer interventions in support of education is a sensible priority. In particular, given the associated health and nutrition impacts of deteriorating livelihoods, understanding the degree to which demand side programmes can integrate interventions in support of broader health and cognitive development objectives is key ${ }^{6}$.

\subsection{Re-orienting Education}

As outlined above, in the context of climate change there is also a clear need to reconsider existing approaches to education, and especially their potential to provide learners with education and training that will help them to respond to a diverse and rapidly changing world. Although we have argued that educational responses to climate change should not consist solely of adding new 'inputs' to curricula, we recognise that addressing climate change (and promoting sustainable development more generally) does also require the promotion of some key areas of knowledge and skills. These will be needed at all levels (primary, secondary, tertiary, and adult education) as well as via diverse modes of delivery (formal, non-formal, professional development).

There are likely to be a wide range of specific topics and content areas which are needed to address climate/ environmental change and impacts, and this may vary significantly

\footnotetext{
${ }^{6}$ See, for example, the multi-agency 'Focusing Resources on Effective School Health' (FRESH) initiative (http://www.freshschools.org/Pages/default.aspx).
} 
depending on particular contexts and needs. However, an indicative outline of key areas of knowledge and skills includes:

\section{- Knowledge of climate change and wider environmental processes}

This includes both specific, content-based knowledge (e.g. climate, deforestation, habitat loss, water cycle, soil erosion, air pollution) as well as awareness of strategies to address pressing environmental concerns (e.g. reducing carbon consumption, encouraging low carbon development, reducing deforestation through sustainable forest management, improving water and waste management).

- Knowledge of local environmental conditions, associated risks and management strategies

The precise content of this area will vary from location to location, depending on local and national contexts and concerns. Possible topics might include the annual flood cycle and how to manage it; sustainable agricultural methods; existing areas of pollution and potential strategies for improved water, soil and waste management; sustainable forest management; and awareness of valuable endemic species (both flora and fauna) and how to protect them.

\section{- Disaster risk reduction}

This is a relatively new area of work in international development and research in which communities are supported to identify and plan for emergencies such as natural disasters as well as other environmental risks such as water contamination, soil erosion, deforestation (leading to landslides), and disease resulting from inappropriate waste disposal. Recent research suggests that these participatory strategies can have a considerable impact on community health and well-being ${ }^{7}$.

Furthermore, high quality learning in these areas is most likely to take place when it is supported by appropriate approaches to curricula, pedagogy and systems of assessment (Alexander 2008). Research has frequently shown that systems of assessment in particular can have significant positive and negative impacts on what happens in classrooms (cf. James et al 2007, Vulliamy 1988). Standardised testing, for example, which requires students to show mastery of particular curriculum content is likely to lead schools and teachers to rely on memorisation and rote learning (i.e. teaching to the test), rather than to use activities which develop critical thinking or problem-solving skills. In other words, encouraging high quality teaching requires curricula, teaching approaches and systems of assessment which place value on high quality learning. Recent research on innovative approaches to teaching and learning in multigrade schools in India and Colombia, among other places, provides a useful foundation for future research and strategy development of this kind (cf. Blum and Diwan 2007; Little 2006; Psacharapoulos, Rojas and Velez 1993).

The potential benefits of such an approach are likely to include increased (meaningful) access and completion levels, as well as the encouragement of critical thinking and lifelong learning skills - including 'learning to know', 'learning to do', 'learning to be', and 'learning to live together' (Delors 1996) - which are needed to address climate change and future uncertainty. These skills, in turn, are linked to a wide range of potential inter-connected improvements to health and well-being which have already been identified by research (e.g. reduced infant mortality, reduced fertility, improved child nutrition, and reduced rates of HIV infection).

\subsection{Challenges to Implementation}

\footnotetext{
${ }^{7}$ See, for example, work by the Children in a Changing Climate initiative http://www.childreninachangingclimate.org/default.php.
} 
Clearly there will be significant challenges to incorporating both these areas of knowledge and skills, and to implementing the educational approach outlined, and these will vary greatly depending on the level of education, as well as the local and national contexts being addressed. In primary education, for instance, a core concern is when to introduce the issue of climate change. This decision is important in order not to frighten children and young people, but to empower them to understand and critically engage with climate/ environmental change.

In secondary education, there are often existing tensions between a centralised curriculum and the need to promote locally-based and locally-appropriate knowledge, as well as problems associated with the already overloaded nature of curricula. Identification of the most appropriate issues and areas of knowledge will require cooperation between local, national and international actors. Educators at all levels will also need support and training to deliver quality education about complex, climate-related topics in ways which are both relevant to local environmental, social and political contexts, and which meet wider educational targets (e.g. literacy, numeracy, employability).

The chronic shortage of scientific knowledge and expertise around climate change and its impacts in many developing countries is also a key concern for educators and policy-makers at both secondary and tertiary levels. As an OECD study reported in the 2009 EFA Global Monitoring Report stated:

'The PISA 2006 assessment of scientific literacy among 15-year-old students offers some important lessons... Strong performance in science and awareness of global environmental problems tend to go hand in hand, and both are associated with a sense of responsibility supporting sustainable environmental management. Conversely, weak performance in science is associated with lower awareness of environmental problems. Failure in scientific education will mean less widespread and less informed - public debate on issues such as climate change and wider environmental problems.' (UNESCO 2008: 37)

There are, however, already some opportunities for exchange and support between institutions across the globe which could assist with skills and technological transfer and capacity development. Examples include initiatives such as DFID's DELPHE programme for higher education (British Council 2008) and UNEP's Mainstreaming Environment and Sustainability in African Universities project (see Gough and Scott 2007), as well as the longterm efforts in international professional exchange and skill share by NGOs such as Voluntary Service Overseas (VSO).

\section{Conclusions}

In a recent speech given to graduating university students Professor Lord Nicholas Stern, adviser to the UK Government on the Economics of Climate Change and Development from 2005-2007, stated: 'We have to recognise two challenges of this century - overcoming world poverty and managing climate change, and we stand or fall on these two things' (Stern 2009). It is the contention of this paper that climate change will significantly impact upon education provision and that education in its broadest sense has a critical role to play in response. Education has a proven record in improving child and maternal health while reducing fertility, and it supports environments of innovation and capacity building associated with technological transfer. As Stern noted in his earlier report:

'Fostering a shared understanding of the nature of climate change, and its consequences is critical in shaping behaviour, as well as in underpinning national and international action... Educating those currently at school about climate change will help shape and sustain future policy making, and a broad public and international 
debate will support today's policy-makers in taking strong action now' (Stern 2007: $x x i)$.

However, the pressing nature of climate change requires educational responses which go beyond the simple provision of new curriculum content. Reflection is also needed regarding the relative emphasis placed on educational access and schooling, as opposed to what is actually learnt in classrooms and the degree to which learning equips and empowers people to deal with rapid change. This will in turn require the development of sound pedagogical approaches, curricula, and assessment strategies, as well as of conducive learning environments both inside and outside of educational institutions. Moreover, there is a need to move beyond the MDG focus on primary education to fully exploit the potential of the secondary and tertiary sub-sectors. More attention also needs to be paid to informal education programmes, which in some areas are the only available educational opportunities and which may also be better placed to have immediate impact (cf. Bekalo and Bangay 2002; Blum and Diwan 2007).

We suggest that education of the kind described in this paper has significant potential to both address climate change and to support wider goals for sustainable development - that is, development which attends to the social, economic and environmental dimensions. By focusing on support for education through not only the provision of curriculum content and efforts to increase enrolment, but also approaches to pedagogy, curricula, assessment frameworks and learning environments that support quality learning, we can encourage learning that encompasses both particular areas of knowledge and skill as well as the development of individual's and communities' capacity to deal with future uncertainty and rapid environmental, economic and political change. As those facing the most imminent impact of climate change have effectively expressed:

'Climate change in the context of sustainable development necessitates a holistic approach conducive to a better quality of life within a long-term time frame, rather than one aimed at short-term gains. Sustainable development strategies are multifaceted, taking into consideration economic, social, cultural, environmental, participatory, and political factors that affect human welfare. An optimal level of understanding of climate change in PICT [Pacific Island Countries and Territories] communities can only be fruitfully and effectively realised if the stakeholders are adequately educated to understand the values underpinning sustainable development and to participate in relevant and appropriate action on climate change.' (Pacific Islands Framework for Action on Climate Change 2006-2015: 11)

\section{References}

Alexander, A. (2008) Education for All, the Quality Imperative and the Problem of Pedagogy. CREATE Pathways to Access Series, Research Monograph No 20. CREATE and University of Sussex, Falmer. Available online http://www.createrpc.org/pdf documents/PTA20.pdf.

Asian Disaster Preparedness Center (2008) A Study on Impact of Disasters on the Education Sector in Cambodia. Asian Disaster Preparedness Center, Bangkok.

BBC (2009a) 'A storm brews over food, water and power'. Published online 24 August 2009. Available from http://news.bbc.co.uk/1/hi/sci/tech/8213884.stm

BBC (2009b) 'Pressure rises on school places'. Published online 15 July 2009. Available from: http://news.bbc.co.uk/1/hi/education/8150563.stm.

Bekalo, S. and Bangay, C. (2002) Towards effective environmental education in Ethiopia: problems and prospects in responding to the environment-poverty challenge. International Journal of Educational Development 22(1), 35-46. 
Citation: Bangay, C. and Blum, N. (2010) Education Responses to Climate Change and Quality: Two Parts of the Same Agenda? International Journal of Educational Development 30(4): 335-450.

Bledsoe, C.H., Casterline, J.B., Johnson-Kuhn, J.A., and Haaga, J.G. (Eds.) (1999) Critical Perspectives on Schooling and Fertility in the Developing World. National Academy Press, Washington, D.C.

Blum, N. and Diwan, R. (2007) Small, Multigrade Schools and Increasing Access to Primary Education in India: National Context and NGO Initiatives. CREATE Pathways to Access Series, Research Monograph No. 17. CREATE and National University of Educational Planning and Administration, Falmer and New Delhi. Available online: http://www.createrpc.org/pdf documents/PTA17.pdf.

Bourn, D. (2008a) Education for Sustainable Development in the UK: making the connections between the environment and development agendas. Theory and Research in Education 6(2), 193-206.

Bourn, D. (2008b) Global Skills. London, Learning and Skills Improvement Service. Available online: http://www.Isis.org.uk/Libraries/Documents/GlobalSkills\%20Nov08 WEB.sflb

British Council (2008) DeIPHE Annual Report, 2007-08. British Council, London.

Carter, R.M., de Freitas, C.R., Goklany, I.M., Holland, D., Lindzen, R.S., Byatt, I., Castles, I., Henderson, D., Lawson, N., McKitrick, R., Morris, J., Peacock, A., Robinson, C., and Skidelsky, R. (2006) The Stern Report: a dual critique. World Economics 7(4), 165-232.

Chambers, R. (2008) Revolutions in Development Inquiry. Earthscan and Institute for Development Studies, London.

Costello, A., Abbas, M., Allen, A., Ball, S., Bell, S., Bellamy, R., Friel, S., Groce, N., Johnson, A., Kett, M., Lee, M., Levy, C., Maslin, M., McCoy, D., McGuire, B., Montgomery, H., Napier, D., Pagel, C., Patel, J., Puppim de Oliveira, J.A., Redclift, N., Rees, H., Rogger, D., Scott, J., Stephenson, J., Twigg, J., Wolff, J., and Patterson, C. (2009) Managing the Health Effects of Climate Change. The UCL Lancet Commission, London.

Courtenay-Hall, P. (1997) Environmental education in a democratic society. In: Wellington, A., Greenbaum, A. and Cragg, W. (Eds.), Canadian Issues in Environmental Ethics. Broadview Press, Toronto, pp. 363-385.

Courtenay-Hall, P. and Rogers, L. (2002) Gaps in Mind: Problems in environmental knowledge-behaviour modelling research. Environmental Education Research 8(3), 284 297.

CREATE (2008) Impact of Health on Education Access and Achievement. Policy Brief Number 3. CREATE and University of Sussex, Falmer.

Das, P.K. (2008) Responding to the Past, Preparing for the Future: Post Sidr Interventions in Education Bangladesh. DFID Bangladesh, Dhaka.

Delors, J. (1996) Learning: The Treasure Within. Report to UNESCO of the International Commission on Education for the Twenty-first Century. UNESCO, Paris.

Elimu Yetu Coalition (2005) The challenge of educating girls in Kenya. In: Aikman, S. and Unterhalter, E. (Eds.), Beyond Access: Transforming Policy and Practice for Gender Equality in Education. Oxfam, Oxford, pp. 106-127.

European Commission (2009) Responding to Climate Change: Sector Script for Education. Available online: http://www.environmentintegration.eu/index2.php?option=com docman\&task=doc view\&gid=42\&ltemid=278.

Freire, Paulo. (1972) Pedagogy of the Oppressed. Penguin Books Ltd., Middlesex.

Freire, Paulo. (1976) Education: The Practice of Freedom. Writers and Readers Publishing Cooperative, London.

Gough, S. and Scott, W. (2007) Higher Education and Sustainable Development: Paradox and Possibility. Routledge, London.

Haichour, E.H, Metzger, J., and Pigozzi, M.J. (2007) 'Learning in the $21^{\text {st }}$ Century: Supporting and guiding education reform for $21^{\text {st }}$ Century learning'. Unpublished paper for the CISCO corporation.

Heimlich, J. and Ardoin, N. (2008) Understanding behavior to understand behavior change: a literature review. Environmental Education Research 14(3), 215-237.

Huckle, J. and Sterling, S. (Eds.) (1996) Education for Sustainability. Earthscan Publications, London. 
Citation: Bangay, C. and Blum, N. (2010) Education Responses to Climate Change and Quality: Two Parts of the Same Agenda? International Journal of Educational Development 30(4): 335-450.

Illeris, K. (2007) How We Learn: Learning and Non-learning in School and Beyond. Routledge, London.

International Council on Human Rights Policy (2008) Climate Change and Human Rights: A Rough Guide. International Council on Human Rights Policy, Versoix, Switzerland.

James, M., McCormick, R., Black, P., Carmichael, P., Drummond, M., Fox, A., MacBeath, J., Marshall, B., Pedder, D., Procter, R., Swaffield, S., Swann, J., and Wiliam, D. (2007) Improving Learning How to Learn: Classrooms, Schools and Networks. Routledge, New York.

Jickling, B. and Spork, H. (1998) Education for the environment: a critique. Environmental Education Research 4(3), 309-329.

Jukes, M.C.H., Drake, L.J. and Bundy, D.A.P. (2008) School Health, Nutrition and Education for All: Levelling The Playing Field. CABI Publishing, Wallingford.

King, K., McGrath, S. and Rose, P. (2007) Beyond the basics: educating and training out of poverty. International Journal of Educational Development 27(4), 349-357.

Klinsky, S. and Dowlatabadi, H. (2009) Conceptualisations of justice in climate policy. Climate Policy 9(1), 88-108.

Kollmuss, A. and Agyeman, J. (2002) Mind the gap: why do people act environmentally and what are the barriers to pro-environmental behaviour? Environmental Education Research 8(3), 239-260.

Lewin, K. (2007) Improving Access, Equity and Transitions in Education: Creating a Research Agenda. CREATE Pathways To Access Series, Research Monograph No 1. CREATE and University of Sussex, Falmer. Available online: http://www.createrpc.org/pdf documents/PTA1.pdf.

Little, A.W. (Ed.) (2006) Education for All and Multigrade Teaching: Challenges and Opportunities. Springer, Dordrecht.

McKeown, R. and Hopkins, C. (2003) 'EE $\neq$ ESD: defusing the worry'. Environmental Education Research 9(1), 117-128.

Mezirow, J. (2000) 'Learning to think like an adult: core conceptions of transformation theory' in Mezirow, $\mathrm{J}$ and Associates (Eds.) Learning as Transformation: Critical Perspectives on a Theory in Progress. Jossey-Bass, San Francisco.

Nussbaum, M. (2000) Women and Human Development: The Capabilities Approach. Cambridge University Press, Cambridge.

Pacific Islands Framework for Action on Climate Change 2006-2015. Available online: http://www.sprep.org/climate change/PYCC/documents/PIFACC.pdf.

Palmer, J.A. (1998) Environmental Education in the $21^{\text {st }}$ Century: Theory, Practice, Progress and Promise. Routledge, London.

Pigozzi, M.J. (2007) Quality in education defines ESD. Journal of Education for Sustainable Development 1(1), 27-35.

Psacharapoulos, G., Rojas, C. and Velez, E. (1993) Achievement Evaluation of Colombia's Escuela Nueva: Is multigrade the answer? Comparative Education Review 37(3), 163276.

Rickinson, M. (2001) Learners and learning in environmental education: a critical review of the evidence. Environmental Education Research 7(3), 207-320.

Robottom, I. and Hart, P. (1993) Research in Environmental Education: Engaging the Debate. Deakin University Press, Geelong.

Save the Children. (2008) Legacy of Disasters: The Impact of Climate Change on Children. Save the Children UK, London. Available online: http://www.savethechildren.org.uk/en/docs/legacy of disasters.pdf.

Scott, W. and Vare, P. (2008) Education for Sustainable Development: Two Sides and an Edge. DEA Thinkpiece. Development Education Association, London. Available online: http://www.dea.org.uk/resources/item.asp?d=884.

Sen, A. (1999) Development as Freedom. Oxford University Press, Oxford. 
Citation: Bangay, C. and Blum, N. (2010) Education Responses to Climate Change and Quality: Two Parts of the Same Agenda? International Journal of Educational Development 30(4): 335-450.

Smith, D. and Vivekananda, J. (2007) A Climate of Conflict: The Links Between Climate Change, Peace and War. International Alert, London. Available online: http://www.international-alert.org/pdf/A Climate Of Conflict.pdf

Sterling, S. (2001) Sustainable Education: Re-visioning Learning and Change. Schumacher Briefing No 6. Green Books, Totnes.

Stern, N. (2009) 'Lord Stern warning'. Published online 4 August 2009. Available online: http://www.brighton.ac.uk/news/2009/090804sternwarning.php?Pageld=810.

Stern, N. (2007) The Economics of Climate Change: The Stern Review. Cambridge University Press, Cambridge.

UNCED. (1992) Agenda 21, The United Nations Programme of Action from Rio. United Nations, New York.

UNDP. (2007) Human Development Report 2007/2008, Fighting Climate Change: Human Solidarity in a Divided World. UNDP, New York.

UNESCO. (2008) Overcoming Inequality: Why Governance Matters. Education For All Global Monitoring Report 2009. UNESCO, Paris.

UNESCO. (2006) Framework for the UN DESD International Implementation Scheme. UNESCO, Paris.

UNESCO. (2004) Education for All: The Quality Imperative. Education For All Global Monitoring Report 2005. UNESCO, Paris.

UNICEF UK. (2008) Our Climate, Our Children, Our Responsibility: The Implications of Climate Change for the World's Children. UNICEF UK, London. Available online: http://www.unicef.org.uk/campaigns/publications/pdf/climate-change.pdf.

USAID. (2007) Adapting to Climate Variability and Change: A Guidance Manual for Development Planning. USAID, Washington, DC. Available online: http://www.usaid.gov/our work/environment/climate/docs/reports/cc vamanual.pdf.

Vulliamy, G. (1988) 'Environmental education in Third World schools: rhetoric or realism' in Briceno, S. and Pitt, D.C. (Eds.) New Ideas in Environmental Education. Croom Helm, London.

Wade, R. and Parker, J. (2008) EFA-ESD Dialogue: Educating for a Sustainable World. Education for Sustainable Development Policy Dialogue No 1. UNESCO, Paris.

Walker, G. and King, D. (2008) The Hot Topic: What We Can Do About Global Warming. Harcourt, Orlando, Florida.

WHO (2008) Climate Change and Human Health: Risks and Responses. World Health Organization, Geneva. Available online: www.who.int/globalchange/publications/cchhbook/en/index.html.

World Bank (2009) Convenient Solutions to an Inconvenient Truth: Ecosystem-based Approaches to Climate Change. World Bank, Washington, D.C.

World Bank. (2008) Climate Change - Adaptation and Mitigation in Development Programs: A Practical Guide. Environment Department, Sustainable Development Network. World Bank, Washington, D.C. Available online: http://siteresources.worldbank.org/EXTEEl/Resources/DCCToolkitCRAlores.pdf. 